УДК 821.161.1 Акунін

Галич Олександр, доктор філологічних наук, професор, професор кафедри державного управління, документознавства та інформаційної діяльності

Національний університет водного господарства та природокористування (м. Рівне)

\title{
ПОЧАТОК ВЕЛИКОЇ МІСТИФІКАЦІЇ: «АЗАЗЕЛЬ» Б. АКУНІНА
}

У статті проаналізовано появу у свідомості читачів постаті головного героя ииклу романів Б. Акуніна Ераста Петровича Фандоріна, молодого детектива, наділеного великими інтелектуальними здібностями, аналітичним складом розуму, безстрашністю $\check{u}$ хоробрістю, умінням передбачати наступні ситуації. Для цього автор аналізує перший твір 
циклл, роман “Азазель”, написаний Б. Акуніним 1998 року. Вигадана біографія героя цього роману поклала початок великій містифікації письменника, щчо вилилася у квазібіографію в наступних творах циклу.

Ключові слова: біографія, квазібіографія, містифікачія, детектив, супергерой.

\section{The beginning of the great mystification: "Azazel” by B. Akunin}

This article analyzes the appearance in the minds of readers of the character of the protagonist of the cycle of novels by B. Akunin Erast Petrovich Fandorin, a young policeman endowed with great intellectual abilities, analytical composition of reason, fearlessness and bravery, and the ability to predict the following situations. For this, the author analyzes the first work of the cycle, the novel "Azazel", written by B. Akunin in 1998. The fictional biography of the hero of this novel marked the beginning of the great mystique of the writer, which resulted in the quasi-biography in the subsequent works of the cycle.

Key words: biography, quasi-biography, mystification, detective story, superhero.

Коли двадцять років тому, у лютому 1998 року, вийшов роман Б. Акуніна «Азазель», ніхто не думав, що він стане початком гігантського творчого проекту письменника, сутністю якого стане впровадження у свідомість читачів образу Ераста Петровича Фандоріна як неперевершеного детектива всіх часів i народів, чия біографія, точніше квазібіографія стане обростати все новими подробицями й легендами, до якої будуть залучені цілі покоління предків і нащадків, а географічним простором стане ледве не вся земна куля: Росія, Англія, Німеччина, Франція, Японія тощо. I ось, у лютому 2018 року, 3'являється останній роман фандоріани, з інтригуючою назвою «Не прощаюся», що ніби передвіщає - творчий проект буде продовжено.

Про Б. Акуніна чимало вже написано, але праць, у яких би постать Ераста Петровича Фандоріна розглядалася з позицій квазібіографії, досі немає.

Метою нашої розвідки є спроба простежити, як у романі «Азазель» автор прагне довести поступовість розгортання біографії його героя - Ераста Петровича Фандоріна, котра в наступних творах перетворюється у квазібіографію, яка потверджується розгалуженим родовим деревом героя, де представлені його численні предки й нащадки.

А починалася історія життя і діяльності цього вигаданого фантазією письменника героя в романі «Азазель» досить просто, як і в багатьох детективах інших авторів. У Москві в Олександрійському саду сталася надзвичайна подія. Юнак «у вузьких картатих панталонах, сюртуці, недбало 
розстебнутім над білим жилетом, $i$ круглому швейцарському капелюсі» [Акунин 2010 : 4], покінчив життя самогубством пострілом у скроню. Автор навіть указує точний час цієї події, понеділок 15 травня 1876 року, о третій годині дня.

Обставини склалися так, що розслідувати справу про це самовбивство взявся дрібний чиновник чотирнадцятого класу, колезький реєстратор Ераст Петрович Фандорін, який лише третій тиждень служив у розшуковому управлінні, а його начальник, Ксаверій Феофілактович Грушин не бачив у цього юнака жодних перспектив заявити про себе в справі розшуку злочинців, примушуючи його втретє переписувати тижневий звіт для обер-поліцмейстера. Юний Фандорін «дев’ятнадияяти років від народження залишився круглим сиротою - матері змалку не знав, а батько, гаряча голова, пустив статки на порожні прожекти, та й наказав довго жити» [Акунин 2010 : 8]. Старий слідчий Грушин жалів юнака: «Хлопчику б гімназію закінчити, та в університет, а замість цуього - геть з рідних стін на вулищю, заробляй на шматок хліба» [Акунин 2010 : 8-9].

Дрібний поліцейський чиновник Грушин, читаючи на службі «Московские ведомости», столичну газету, яка видавалася в Москві з 1756 до 1917 року, серед інших газетних новин звернув увагу свого підлеглого, головного героя твору Фандоріна, на такі новини: «Найновіший американський корсет “Лорд Байрон” з найміцунішого китового вуса для чоловіків, щуо бажають бути стрункими. Талія в дюйм, плечі в сажень» [Акунин 2010 : 10]. На перший погляд, це повідомлення, прочитане Грушиним, не знайшло жодної зовнішньої реакції у Фандоріна, хіба що, щоки у нього почервоніли, проте Грушин не звернув на це увагу. Сам же Фандорін виявляється, ніби прогнозуючи своє подальше майбутнє, «позавчора витратив третину свого першого місячного жалування на такий хвацько розрекламований корсет» [Акунин 2010 : 11], що через кілька днів саме він врятував життя молодому слідчому-початківцю. Грушин читає ще кілька новин 3 газети: «3вірства турецььких башибузуків у Болгарї̈» [Акунин 2010 : 11], «Вибух на Ліговці» 
[Акунін 2010 : 12], але особливу увагу звертає на таке повідомлення: «Відома англійська благодійниия Естер, зусиллями якої в різних краӥнах влаштовані так звані “екстернати”, зразкові притулки для хлопчиків-сиріт, оголосила намому кореспонденту, що і в златоглавій, нарешті, відкрилися двері першого закладу подібного роду. Леді Естер, з минулого року розпочала свою діяльність у Росії $i$ вже встигла відкрити екстернат в Петербурзі, вирішила облагодіяти $i$ московських сиріток...» [Акунин 2010 : 13]. Старий поліцейський, читаючи за звичкою газету, не розуміє, що саме ця новина стане ключовою в розслідуванні, яке через кілька хвилин розпочне молодий Фандорін. Зав'язкою цьому розслідуванню, а отже й роману послужить наступна новина, вголос прочитана Грушиним, що в «Московских відомостях» названа «Цинічний вчинок»: «Вчора в Александрівському саду відбулася печальна подія в дусі ичинічних норовів сучасної молоді. На очах у тих, хто прогулювався, застрелився пан N., статний молодецьь 23-х років, студент М-ського університету, єдиний спадкоємець мільйонного статку» [Акунин 2010 : 13]. Прочитавши це повідомлення, Ксаверій Феофілактович Грушин одразу дає доручення своєму підлеглому Фандоріну, який нещодавно був зарахований на службу в московську поліцію, з'ясувати в другій дільниці про обставини цієї пригоди, а якщо $є$ посмертна записка, то переписати іiї зміст, мотивуючи власне прохання тим, що його дружина, Свдокія Андріївна, любить дізнаватися від чоловіка про різні сенсації. Якщо для Грушина це газетне повідомлення $\epsilon$ звичайною буденною цікавинкою, 3 якою він після служби увечері хоче поділитися 3 дружиною, то для молодого Фандоріна, це - здійснення мрії, можливість зайнятися справжнім розслідуванням реальної справи.

Переглянувши матеріали справи про самогубство студента, Фандорін дізнався його ім'я - Петро Олександрович Кокорін. «Олександра Артемоновича Кокоріна синок, - пояснив Іван Прокопович, худий, довготелесий служака з пом'ятим, наче корова лизала, обличчям. - Надзвичайно багатою була людина. Заводчик. Три роки як помер. Все сину відписав. Жив би собі студент та радів» [Акунин 2010 : 16]. Із передсмертної записки Фандоріна 
зацікавив бювар, який не виявився у покійного, хоча той наголошував: «...Я не закінчена скотина, свідченням тому є шкіряний бювар» [Акунин 2010 : 18].

Розпочавши першу свою справу, дев’ятнадцятилітній Фандорін був «дивовижно схожий на однорічного сеттера, вперше випущееного в ліс $i$ очманілого від гостро-звабливого запаху близької дичини» [Акунин 2010 : 21]. Він зразу знайшов бювар у квартирі покійного студента. У ньому був лише один документ, заповіт, згідно 3 яким все майно багатого спадкоємця переходило до британської підданої пані Естер.

Справа Кокоріна заохотила початківця. Він звернув увагу на ті обставини, що не помітили в поліції: «Тут якась таємниця, чесне слово! - I вперто підкреслив. - Так, саме, таємниия! Подумайте самі. По-перше, застрелився якось безглуздо, навмання, однією кулею з барабану, ніби й зовсім не збирався стрілятися. Що за фратальне невезіння! I тон передсмертної записки, погодьтеся, якийсь дивний - начебто якось наспіх, між ділом написана, а між тим проблема там порушена найважливіша. Неабияка проблема! - голос Ераста Петровича аж задзвенів від почуття. - Але про проблему я ще потім скажу, а поки про заповіт. Хіба він не підозрілий?» [Акунин 2010 : 25]. Фандорін уже встиг навести довідку, що покійний залишив величезний спадок: «ві фабрики, три заводи, будинки в різних місиях, верфі в Любаві, одних процентних паперів у Державному банку на півмільйона!» [Акунин 2010 : 26]. Фандорін вирішує 3’ясувати зв’язок між загиблим студентом-мільйонером i британською леді Естер. А перед цим він вирішує допитати прикажчика Кукіна та поміщицю Спицину, які бачили якогось студента, що в той же день, як i Кокорін, пробував покінчити життя самогубством, про що Ераст Петрович дізнався від свого начальника Грушина, котрий вичитав про це у свіжій московській газеті. 3 опису Спициної Фандорін зрозумів, що вона бачила саме Кокоріна. Однак покази прикажчика Кукіна були протилежними. Він бачив саме студента в мундирі, а не в сюртуці, який виявився на загиблому Кокоріну.

Б. Акунін наділяє юного Фандоріна аналітичним складом мислення. Швидко проаналізувавши ситуацію, він вирішує допитати доньку дійсного 
таємного радника сімнадцятилітню Слизавету Олександрівну фон ЕвертКолокольцеву та іiі гувернантку дівицю Емму Пфуль, 48 років, на очах яких відбувся акт самогубства Кокоріна. У своїх припущеннях Фандорін не помилився. Пані Пфуль повідомила йому, що бачила на місці події сутулого студента, опис якого нагадував портрет того, про кого свідчив прикажчик Кукін: «Повідомлення дівищуі Пфуль, безумовно, мало виняткову важливість» [Акунин $2010: 46]$.

Недаремно воно зацікавило безпосереднього начальника Фандоріна Грушина: «Наступного дня об одинадиятій годині ранку Ераст Петрович, благословенний начальником $i$ навіть наділений трьома рублями на екстраординарні витрати, прибув до жовтого корпусу університету на Моховій. Завдання було нескладним, але таким, щзо потребувало відомого везіння: розшукати сутулого, не примітного собою $i$ почасти прищавого студента в пенсне на шовковій стрічщіџ [Акунин 2010 : 47]. Із завданням Фандорін упорався за кілька годин. У московському університеті він встиг дізнатися, що сутулим прищуватим студентом, що носить пенсне на шовковій стрічці є Микола Степанович Ахтирцев, як його характеризує прислужник Митрич, «найперший багач, княжої крові» [Акунин 2010 : 49]. Саме той Ахтирцев, який у заповіті зазначений виконувачем духівниці. Того ж дня Фандорін не лише познайомився з Ахтирцевим, але й став свідком його смерті. При цьому й сам отримав поранення ножем в бік. Йому запам'яталося останнє слово, вимовлене вмираючим студентом “Азазель”.

Б. Акунін вміло підігріває інтригу першого свого роману про Фандоріна. Смерть Ахтирцева, «рідного онука його світлості канщлера Корчакова» [Акунин 2010 : 81] (очевидно, Олександра Михайловича Горчакова, тут і в низці наступних романів письменник часто користується прийомом прозорої зміни прізвища героя шляхом заміни однієї чи двох літер у ньому) сполошила Санкт-Петербург. Для розгляду справи 3 столиці до Москви прибуває спеціальний слідчий, чиновник 3 особливих доручень при шефі жандармів і начальнику Третього відділення Іван Францевич Бриллінг, який відвідав дома 
пораненого Фандоріна. Побачивши його досить скромні матеріальні можливості, петербурзький чиновник, високо оцінивши доповідь про події останнього, розпорядився видати йому п’ятсот рублів преміальних і запросив працювати над версіями разом. Від Бриллінга Фандорін дізнається, що Азазель - «ие грішний ангел... Одним словом, бунтівний демон, дух вигнання» [Акунин 2010 : 89].

Петербурзький чиновник назвав три можливі версії вбивства Ахтирцева i поранення Фандоріна. Останній назвав і вірогідну четверту версію: «...Bu даремно залишаєте осторонь леді Естер. Вона, звичайно, вельми шанована й поважна особа, але... але все ж мільйонний заповіт!» [Акунин 2010 : 93]. На що Бриллінг відповів: «Ім'я баронеси Естер виникло випадково. Я не включив ї̈ до списку підозрюваних, по-перше, тому, щуо час є дорогим, а по-друге, щуе й тому, щзо я цүю пані трохи знаю, мав щзастя зустрічатися» [Акунин 2010 : 93]. Проте він не заборонив Фандоріну зустрітися з леді Естер.

Естер виявилася «сивуватою пані не просто приємної, а якоїсь затишної зовнішності. Їі яскраво-блакитні оченята за золотим пенсне так $і$ світилися живим розумом і привітністю. Некрасиве, рухливе обличчя з качиним носиком $i$ иироким, усміхненим ротом Фандоріну зразу сподобалось» [Акунин 2010 : 98]. Перший візит до леді Естер був невдалим, Фандорін нічого нового від неї не дізнався, що послужило причиною іронічного зауваження Бриллінга: «Ну, щ⿻о взяли злодійку на гарячому» [Акунин 2010 : 106]. Він же доручив Фандоріну зайнятися графом Зуровим, з яким той уже бачився в Амалії Бежецької, що безслідно зникла після вбивства Ахтирцева й поранення Фандоріна. Бриллінг вважав, що вона $є$ тією ниточкою, що дасть можливість розкрити причини самогубства студента Кокоріна.

Зуров тримав напівлегальний гральний притон, де збиралися картярі. Фандорін $з$ першого разу виграв у Зубова в карти (До того він жодного разу в карти не грав і лише перед походом до Зубова отримав перший урок у свого начальника про картяжну гру). Програвшись, Зубов викликав Фандоріна на дуель, з якої останній вийшов без ушкоджень, оскільки його суперник наказав 
слузі підмінити набої. Зуров, прийнявши Фандоріна за одного з поклонників Амалії, дав іiі лист, де вона називає свою лондонську адресу. Цей аргумент Фандорін вважає важливим, у розмові з Бриллінгом він наполягає на розробці власної версії, головною фігурою якої $є$ Амалія Бєжецька. Петербурзький чиновник вважає ж головною версією - пошук нігілістів. I все ж він погоджується на термінове відрядження до Лондона, для цього домагається позачергового присвоєння Фандоріну звання титулярного радника й зарахування на посаду кур'єра першої категорії по відомству міністерства закордонних справ. Щоб не викликати підозр він мав по дорозі розвести дипломатичну пошту до Берліна, Відня і Парижа.

Прибувши інкогніто до Лондона, Ераст Петрович Фандорін, як це i повинно бути в пригодницькому романі, переживає декілька смертельних пригод, із яких виходить переможцем. Він розшукує Амалію Бєжецьку i викрадає в неї портфель 3 дивними листами 3 різних континентів. Невдовзі портфель у нього забирають, однак він встиг прочитати зміст записів, всього їх було сорок п’ять. Слуги Бєжецької зв’язали Фандоріна і закутали в мішок. «Відвезуть його до якогось глухого причалу, прив'яжуть камінь і відправлять на дно Темзи, гнити серед іржавих якірних ланщюгів $і$ осколків пляшок» [Акунин 2010 : 178], - думав новоспечений титулярний радник, гарячково намагаючись знайти вихід із, здавалося б, безвихідної ситуації. I він його знаходить. Допомагає стилет, схований у правому рукаві. Перед тим, як Фандоріна кинули в річку, він знову почув від одного з його катів Франца слово “Azazel!” [Акунин 2010 : 181].

Врятувавшись від одних мучителів, Фандорін несподівано потрапив на мушку Пижова, працівника російського посольства в Лондоні, до якого рекомендував звернутися Бриллінг. Вистрілити зрадник не встиг, його випередив... Зубов.

Останній виявився непричетним до розслідування Фандоріна. Він дав йому адресу готелю, у якому повинна була бути Амалія, щоб забути цю жінку, у яку закохався, а потім його замучили ревнощі, і Зубов помчав до Лондона, 
ладен убити обох, Амалію і іï коханця, вважаючи, що це Фандорін. Розповівши все це останньому, Зубов, прощаючись 3 ним, заявляє про свій намір пристрелити Амалію Бєжецьку. Однак пізніше Фандорін дізнався від леді Естер, що Зубов не вбив Амалію, а кудись вивіз: «Зараз, правда, вона веде себе нерозумно і на час забула про обов'язок. 3 молодими жінками цее трапляється. Але вона неодмінно до мене повернеться, я знаю свойх дівчаток» [Акунин $2010: 263]$.

Б. Акунін, розвиваючи інтригу сюжету свого роману, примушує Фандоріна знайти спосіб дістатися до Санкт-Петербурга раніше, ніж туди дійде лист від Амалії. Далі події роману стрімко пришвидшуються: Фандорін уже в російській столиці дізнається, кому адресовано лист із Лондона. Адресатом виявився Джеральд Каннінгем, один із помічників леді Естер. Про свої пригоди в Англії і підозри Фандорін доповідає Бриллінгу, який того дня виявився в Санкт-Петербурзі. Останній вирішує арештувати Каннінгема і бере для цього Фандоріна. А потім несподівано вбиває англійця. На запитання Фандоріна, навіщо?, відповів: «Його згубили ви... Ви надто хороший детектив. I тому, мій юний друже, мені доведеться вас убити, про щзо я щзиро жалкую» [Акунин 2010 : 227].

Б. Акунін зберігає життя Фандоріну, натомість гине Бриллінг, який, як зрозумів молодий слідчий, був одним із представників Азазель, міжнародного злочинного угрупування, до якого входили тисячі людей різних національностей. Об’єднуючою ознакою всіх їх було раннє сирітство, відсутність родичів. Таким був і Бриллінг, який за підтримки Азазель зробив стрімку кар’єру в правоохоронних органах Російської імперії.

Фандорін починає розуміти, що за всім цим стоїть леді Естер. Він негайно виїздить до Москви і одразу з поїзда їде до притулку, яким керує англійка. Це виявилося його помилкою. Він знову ледве не загинув, дивом урятувавшись від неминучої загибелі. Зате з уст леді Естер Фандорін дізнався, що таке насправді Азазель: «Азазель - не сатана, мій хлопчику. Це великий символ спасителя $i$ просвітителя людства. Господь створив ичей світ, створив людей $і$ залишив їх 
самим собі. Проте люди слабкі і так сліпі, вони перетворили божий світ у пекло. Людство давно б загинуло, якби не особливі особистості, щуо час від часу з'являються серед людей. Вони не демони і не боги, я зву їх hero civilisateur. Завдяки кожному з них людство робило стрибок уперед» [Акунин 2010 : 283]. Леді Естер називає Фандоріну імена Мойсея, Христа: «Але найцінніший із иих героїв - іудейський Азазель, щэо навчив людину почуттю власної гідності... Бог лише здав людині карти, Азазель же вчить, як треба грати, щоб виграти. Кожен із моїх вихованців - Азазель, хоча $i$ не всі про ие знають» [Акунин 2010 : 284]. Далі леді Естер скаже Фандоріну: «Азазель» - мій передовий загін, котрий повинен поволі, поступово прибрати до рук штурвал управління світом» [Акунин $2010: 284]$.

Наступні цикли романів, героєм яких є Фандорін, або згадується його ім'я, часто наповнені реальними героями, яких мало в першому творі письменника. Одним із них $\epsilon$ московський генерал-губернатор Володимир Андрійович Долгорукий, який кілька разів присутній в романі, скоріше, не як персонаж, а як епізодична постать. Зокрема, в “Азазель” московський градоначальник вітає Фандоріна в день весілля в Златоустинській церкві: «Особливо сподобався генерал-губернатор Володимир Андрійович Долгорукий повний, добрий, круглолиций, з відвислими вусами» [Акунин 2010 : 292]. Саме тісна співпраця 3 Долгоруким стане для Фандоріна справою життя в низці наступних творів Б. Акуніна. 3 Володимиром Андрійовичем Долгоруким пов'язують небувале економічне зростання Москви, розвиток залізничного транспорту. Друга на той час російська столиця тримала першість у реформах міського управління, судової системи, земства, саме за часів губернаторства Долгорукого з'явилося електричне освітлення, телефонний зв'язок, кінний трамвай. Поліція, а саме в цьому відомстві, за версією Б. Акуніна, продовжилася трудова діяльність героя низки його наступних творів Фандоріна, діяла в Москві набагато успішніше, ніж в інших регіонах Російської імперії. Отож, у наступних романах градоначальник буде грати значно помітнішу роль у житті Фандоріна. 
Закінчується ж «Азазель» подією, що робила головного героя найщасливішою людиною на світі, весіллям 3 Лізонькою ЕвертКолокольцевою, і водночас - найтрагічнішою, іï загибеллю саме в день весілля. Коли після вибуху Фандорін зрозумів, що живий, він не одразу помітив на землі предмет: «Тонка, відірвана по лікоть дівоча рука, що поблискувала золотою обручкою на безіменному пальиі〉 [Акунин 2010 : 299]. Така натуралістична деталь ніби підкреслює глибину трагедії, яка могла на цьому припинити біографію героя Б. Акуніна. Натомість він одержав «винятково білі, наче приморожені інеєм виски» [Акунин 2010 : 299], що будуть супроводжувати портретні характеристики героя в наступних творах.

Таким чином, перший роман Б. Акуніна про Фандоріна впроваджує в російську історію постать молодого детектива, наділеного великими інтелектуальними здібностями, аналітичним складом розуму, безстрашністю й хоробрістю, умінням передбачати наступні ситуації. По суті, письменник створює біографію молодої людини останніх десятиліть ХІХ ст., яка завдяки вписуванню в історичні реалії, знайомству з справжніми людьми свого часу, співпраці 3 ними, в наступних творах перетворює іiі на квазібіографію супергероя.

\section{БІБЛІОГРАФІЯ}

Акунин 2010 - Акунин Борис. Азазель / Борис Акунин. - Москва : Захаров, 2010. - 302 с. 